\title{
Measuring Employees' Performance in the Public Sector in Sri Lanka: Testing of Two Models
}

\author{
Dhammika K.A.S. \\ Department of Human Resource Management \\ University of Kelaniya, Kelaniya,Sri Lanka \\ kasdhammika@yahoo.com
}

\begin{abstract}
Performance of employees of an organization is a key concern of managers irrespective of their level and position. This is highly relevant when an organization is experiencing a down word trend or a standstill in their employees' performance. Assessment of employees' performance is required for effective performance management in organizations. However, a relatively little attention has been paid by researchers for the identification of an appropriate model of performance for employees in Sri Lankan context particularly for the public sector. The purpose of this reported study was to test the two alternative models of performance on their goodness for assessing the performance the employees of the selected public sector organizations in Sri Lanka. A sample of 200 employees was selected representing 11 public sector organizations for the study. Standard questionnaire was used for the data collection which assesses the performance on dimensions of the two models and both exploratory and confirmatory
\end{abstract}


factor analysis were applied for the analysis of data. It was found that the role based model of performance recorded better model fit statistics over two factor model. The study revealed that the behavioral factors such as the job, career, team, innovator and organization are important aspects to be concerned in assessment of performance of employees. Both theoretical and practiocal implications of the finding emphazising on performance management were discussed.

Keywords: Employee performance, Task and contextual performance, Role based performance.

\section{Introduction}

The concept of work performance in organization has been subjective to the changes over the past years with the dynamism of the organizational environment (Chen \& Klimoski, 2003). Employee performance or job performance in other words, is defined as individuals' behaviors regarding self-control and those affecting achievement of organizational goals (Campbell, 1990). Rotundo and Sackett (2002) define performance as those actions and behaviors that are under the control of the individual and contribute to the goals of the organization. Employee performance generaly refers to the amount of output generated from job execution by an employee over a particular period of time in an organization. The early conception of employee performance largely backed by scientific management 
thought concerned only the quantity of output of doing a job. However, the dimensions of both quantity and quality were added to the employee performance later in assessing performance of employees. Effciency, efficacy, and quality were identified as the major dimensions of employee performance (Lee, Lian, \& Chen, 1999), which received much acceptance among researchers. Efficiency refers to the rate of output on job execution and also meeting the deadlines for finishing job tasks. Efficacy, on the other hand, represents the goal accomplishment rate by a particular employee.

Researchers have utilized various methods for measuring job performance and found various dimensions of it (Luo, Shi, Li, \& Miao, 2008) since employee performance is said to be a multidimensional construct (Befort \& Hattrup, 2003). This has induced both practitioner and researchers to identify the dimensions of employee performance with the aim of managing employee performance in organizations. Thought the constructs of employee performance have been examined extensively in management literature (Borman, et. al,1999), different ideas on the conceptions of performance can be observable. One of the major concern is to measurement of individual work performance in organizational research (Bennett, Lance, \& Wochr, 2014). They claimed that "the criterion problem- the inherent difficulty associated with criterion development, measurement and performance evaluation. Continue to be mainstay of both the popular and academic literature" (Bennett, Lance \& Wocher, 2014, p.5). It is accepted that job performance is a 
multidimensional construct addressing number of dimensions associated (Borman \& Motowidlo, 1993; Campbell, Gasser, \& Oswald, 1996). The most common and accepted two dimensions identified are task performance and contextual performance dimensions (Motowidlo \& Van Scotter, 1994).Task performance defined as behaviors associated with the transformational and maintenance activities of the organization such as production, selling, and purchasing etc. (Motowidlo \& Schmit, 1999).

However, some models such as role based model of performance (Welbourne, Johnson, \& Erez, 1998) is also used for measuring the employee performance in organization. The availability of different approaches and models for assessing the employees' performance has led to the empirical vague of the concept of employee performance (Adelle \& Boris, 2014). However, Griffin, Neal, and Parker, (2007) claimed that "there is no currently theoretical framework for differentiating and integrating the various constructs that describe individual performance and its link to effectiveness" (p.327). Therefore it is required to test the validity of the model used in assessing the performance in studies since employees performance is highly contextual phenomena. The purpose of this paper is to test the goodness of the two alternative model, namely task and contextual performance of Motowidlo and Van Scotter (1994) and the role based model of performance of Welbourne, Johnson, and Erez (1998) and to identify the most suitable model for the assessment of performance of the public sector employees in Sri Lankan. 


\section{Task and contextual Performance}

Borman and Motowidlo, (1993) conceptualized employee performance having two dimensions namely task and contextual performance. The totality of performance of employees on their job should be the aggregation of both task and contextual performance. The task performance is related to the activities of the organizations which are linked with the core transformation process of the organization (Motowidlo \& Schmit, 1999). According to this notation, the task performance captures the core behaviors or expected behaviors on the job by the formal authority of the firm (Befort \& Hattrup, 2003). On the other hand, contextual performance includes the behavior exhibited by an employees which are related to the culture and the context of the organization. Example for such behaviors are helping core workers, following organizational rules and regulations and be loyal to the organization (Motowidlo \& Schmit, 1999).

This conceptualization of employee performance has received much empirical supports from numerous studies (Luo, Shi, Li, \& Miao, 2008). Later, this conception of employee performance expanded further by identifying three constructs namely, task performance, job dedication and interpersonal facilitation (Conway, 1996). The job dedication and interpersonal facilitation are two dimensions of contextual performance identified later. Job dedication includes self- 
disciplined, aggressive and following rules and regulations of the organization which are formulated for achieving organizational goals. On the other hand, interpersonal facilitation encompasses the behaviors such as cooperating with others, understanding others and helping colleagues (Luo, Shi, Li, \& Miao, 2008).

\section{The Role Based Performance Model}

Another widely accepted method of conceptualization of employee performance was the role-based model of performance (Welbourne, Johnson, \& Erez, 1998). A role is generally defined as the total set of performance responsibilities associated with one's employment (Murphy \& Jackson, 1999: p, 335). Role emplyees play on the job are vital for the effectiveness of the organization and measument of employee performance should considere it (Wallace, Edward, Arnorld, \& Frazier, 2009). It is said that the employee behavior on the job determines the level of performance of them (Kappagoda, Othman, Fithri, \& Alwis, 2014). This notation highlights the fact that different behaviors of employees on the job may create what is known as within person differences in job performance. Katz and Kahn, (1978) identified three types of behaviors leading to employees' performance: (1) joining and staying in the organization (2) independently meeting or exceeding standard of performance based on the job role, (3) going beyond the expected actions, which is later conceptualized as organizational citizenship behavior (Organ, 1997). 
Given that the work role performance should include the aspects of organizational context, the role theory provides an improtant approach to describe the full set of work responsibilities (Griffin, Neal, \& Parker, 2007). Variuos type of role based model of performance has been produced by researchers. Welbourne, Johnson, and Erez, (1998) identified five roles of performance namely, the job role, carrer role, innovator role, team role and organization role behavior. Expaning the roel theory further, Podsdakoff, MacKenzie, Paine, and Bachrach, (2000) identfied helping behaviors, sportmanship, organizational loyalty, organizational complince, individual initiatives, civic status, and self-development as job related behaviors. They were later termed as organizational citizenship behavior. Individual task behavior, team memebr behavior and organizational member behaviors were the another role modle of performance tested (Griffin, Neal, \& Parker, 2007). However, given that the five role model of performance of Welbourne, Johnson, \& Erez, (1998) is largely validitized, the present study used it as the role based model of performance.

\section{Hypotheses}

Management of employee performance is central in effective management of human resource in organizations. An effective performance measurement system ought to cover all aspects of performance that are relevant to the existence of an organization and the means by which it achieves success and growth (O'Regan, 
Ghobadian, \& Sims, 2005). Employee performance in organizations has found to have significant implications for the overall performance of the organization and its effectiveness irrespective of their nature. Though performance is considered an aggregate concepts, researchers have identified dimensions associated with it and considered it a multidimensional construct (Shaw, Delery, \& Abdulla, 2003). Number of measurement models of employee performance have been developed and tested in the field of management over the past decades (Motowidlo \& Van Scotter, 1994). However, the using an appropriate model for measuring the performance depending of the context is a need for effective performance management system. Keeping with this background, the objective of this study was set to assess the appropriateness of two models, namely task and contextual performance model and role based model of performance for the measuring the performance of the public sector employees in Sri Lanka. Therefore, it was hypothesized here,

$\mathrm{H}_{1}$ : The task and contextual performance model captures the performance of employees significantly in the public sector in Sri Lanka.

H2: The role based model of performance captures the performance of employees significantly in the public sector in Sri Lanka. 


\section{Methods}

\subsection{Sample}

The sample of this study includes 200 public sector employees using simple ranodm sampling. All thses employee are from public sector commercial organizations representing the cross sectional of organizations. Two instruments were administered with the respondents. The first questionare measures the employees performance with the two factors model while the second questionare measures it on five factors model. Questionares were distributed among the resondents personaly and collected after a one week time. Hundred and eighty nine (189) completed questionare were able to collect back. Six (6) quetionares were found to be incomplte so they were excluded from the analysis.

Fivety six percent $(56 \%)$ of the sample is male while the rest $(34 \%)$ represents the male employees. Approximately fifty nine (59\%) percents of employees has a service period of more than 5 years and $41 \%$ of them have served in the current organization for more than 3 years. All of these employees represents the clearical and related employees of the public sector.

\subsection{Measurement}

Employee performance measure was adapted from 20 items of the self-rating instrument of Welbourne, Johnson and Erez (1998). It includes four items designed to assess the perofrmance of employees 
on job, ( e.g. "The quantity of work I do on my job"), career ( e.g. "Developing of skills needed for my future career"), innovator (e.g. "Working to implement new ideas by me on my job"), team (e.g. "Working of me as a part of the team"), and organization (e.g. "Doing things by me to promote the organization"). Each item is rated using five-point Likert scale ranging froml(Need much improvement) to 5 (Excellent). The reliability coeffcient (Conbrach's Alpha) for each dimensions of the measure recorded as $.78, .76, .77, .81$, and .71 for the job, career, team, innovator and organization respectively.

The twenty item measure of task and contextual performance instrument of (Befort \& Hattrup, 2003) was adopted. Nive (09) items of it assess the task performnce while the rest 11 items measure the contextual performance based on five categories of contextaul performance of (Borman \& Motowidlo, 1993). The itesm for task performance (e.g. "I complete all duties that are central to my job") and items for contextual performance (e.g. "I keep corporating with other co-workers") were on 5 point Likert sacle with anchors " Not at all Important" to "Very Important". The reliability coefficent for both dimensions were found to be .78 and .77 respectively.

\subsection{Data Analysis Procedure}

First, the correlation beween the componants of the two model was assesed to check whether significant correaltion exists between the componants. Then the two models of performance was tested 
seperately by using the alternative model testing procedure of structural equation modeling techniques (Byrne, 2010). As the last procudere, the the model with the covariance between the two model was tested. By doing so, it can be identfied the two models were covarinaced each other.

\section{The Results}

The Table I depicts the results of the correlation analysis for each dimensions of the two models.

Table I: Correlation among latent factor of the two construct models

\begin{tabular}{lllllllllll}
\hline Variable & Mean & s.d. & $\mathbf{1}$ & $\mathbf{2}$ & $\mathbf{3}$ & $\mathbf{4}$ & $\mathbf{5}$ & $\mathbf{6}$ & $\mathbf{7}$ & $\mathbf{8}$ \\
\hline 1.Task & 4.1 & 0.65 & 1 & & & & & & & \\
Performance & & & & & & & & & & \\
2.Contextual & 3.3 & 0.87 & .78 & 1 & & & & & & \\
Performance & & & & & & & & & & \\
3.The job & 3.6 & 0.82 & .65 & .67 & 1 & & & & & \\
4.The career & 4.1 & 0.78 & .76 & .59 & .61 & 1 & & & & \\
5.Innovator & 4.2 & 0.78 & .45 & .68 & .65 & .71 & 1 & & & \\
6.Team & 3.5 & 0.67 & .67 & .77 & .71 & .63 & .62 & 1 & & \\
7.Organization & 3.2 & 0.82 & .78 & .71 & .64 & .58 & .57 & .71 & 1 & \\
8. Performance I & 4.2 & 0.89 & .72 & .59 & .56 & .67 & .59 & .72 & .56 & 1 \\
9.Performance II & 3.7 & 0.88 & .56 & .72 & .45 & .70 & .64 & .68 & .67 & .71 \\
\hline
\end{tabular}


Kelaniya Journal of Human Resource Management

Volume 8 Number 1 January 2013

The Table II contains the model fit statistics for each model tested using alternative model testing procedure.

Table II: Model fit statistics of the two model

\begin{tabular}{|c|c|c|c|c|c|c|}
\hline Models & $d f$ & $\chi^{2}$ & GFI & CFI & NNFI & RMSEA \\
\hline $\begin{array}{l}\text { Two Factor Model (Task and } \\
\text { Contextual Performance) }\end{array}$ & 243 & 678.9 & .49 & .42 & .44 & .33 \\
\hline $\begin{array}{l}\text { Two Factors Model (Job and } \\
\text { Career Performance) }\end{array}$ & 243 & 645.2 & .51 & .51 & .56 & .31 \\
\hline $\begin{array}{l}\text { aThree Factors Model (Job, } \\
\text { Career and Innovator }\end{array}$ & 242 & 634.7 & .52 & .67 & .59 & .23 \\
\hline Performance) & & & & & & \\
\hline $\begin{array}{l}\text { Four Factors Model (Job, } \\
\text { Career, Innovator and Team } \\
\text { Performance) }\end{array}$ & 241 & 598.2 & .67 & .77 & .69 & .21 \\
\hline $\begin{array}{l}\text { Five Factors Model (Job, } \\
\text { Career, Innovator, Team, and } \\
\text { Organization Performance) }\end{array}$ & 240 & 523.3 & .87 & .87 & .76 & .15 \\
\hline
\end{tabular}

\section{Findings}

The potential relationship between the factors of the two performance model was tested with the correlation analysis. The results of the correlation analysis is depicted in the Table I. Accordingly, first, a significant and strong association between the task and contextual performance dimensions of the first model was observed $(\mathrm{r}=.78$, $\mathrm{p}<.05$ ). The five components of the second model too recorded a 
significant relationship between each components (Job and Career $(\mathrm{r}=$ $.61, \mathrm{p}<.05))$, Job and Innovator $(\mathrm{r}=.65, \mathrm{p}<.05)$, job and team $(\mathrm{r}=.71$, $\mathrm{p}<.05)$ and job and organization $(\mathrm{r}=.64, \mathrm{p}<.05))$. The overall measure of performance using model I and II too recorded a significant association between each other $(\mathrm{r}=.71, \mathrm{p}<.05)$. This leads to the fact that the two models seem to be satisfactorily suitable for measuring the employees' performance in the public sector.

However, the aim of this study is to identify the best model for assessing the employee performance in the public sector. For this, the alternative model testing procedure with structural equation modeling (Byrne, 2010) was used. The results of the alternative model testing procedure is shown in the Table II.

According to the table II, the two factors model which measures the performance alone task and contextual performance recorded an adequate model fit statistics $(\chi 2=678.9, d f .=243, \mathrm{p}<.05, \mathrm{GFI}=.49$, $\mathrm{CFI}=.42, \mathrm{NNFI}=.44, \mathrm{RMSEA}=.33$ ). This indicated that the employee performance of the public sector employees is adequately captured by the task and contextual performance model. Further, the two factor of model including job and career performance was also tested. This model too fit with the data adequately $\left(\chi^{2}=645, d f .=243, \mathrm{p}<.05\right.$, $\mathrm{CFI}=.51, \mathrm{NNFI}=.51, \mathrm{RMSEA}=.31$ ). However, the second model indicated a better model fit than the first model $(\Delta \chi 2=23.09, \mathrm{p},<.01)$. The second model expanded further by adding other dimensions i.e. 
innovator, and tested separately. It showed that the adding of dimensions improved the model fit further $(\chi 2=634.7, d f .=242, \mathrm{p}$ $<.05, \mathrm{GFI}=.52 \mathrm{CFI}=.67, \mathrm{NNFI}=.59, \mathrm{RMSEA}=.23$ ). The final model which included all five dimension fit with the data more adequately $(\chi 2=523.3, d f .=240, \mathrm{p}<.05, \mathrm{GFI}=.87, \mathrm{CFI}=.87$, NNFI=.76, RMSEA=.15). Further the five factor model (Job, Career, Innovator, Team, and Organization Performance) recorded the best model fit over the all the model tested and it indicted higher model improvement compared to the first mole of task and contextual performance $\left(\Delta \chi^{2}=\right.$ 155.6, $\mathrm{p},<.01)$. This indicated the fact that the five factor model can be used to assess the employees' performance better than the other model tested.

\section{Discussion}

Management of employee performance requires an accurate measurement of employee performance in organizations. Though number of model are available in human resource management for assessing employee performance, the task and contextual performance model (Motowidlo \& Van Scotter, 1994) and role based model of performance (Welbourne, Johnson, \& Erez, 1998) are recorded to be highly accepted two model of performance. In keeping with the aim of this study, the two models were tested to identify the best model for measuring the performance of the employees in the public sector in Sri Lanka. It was found that the five factors model (Job, Career, 
Innovator, Team, and Organization Performance) stand more suitable for the assessing of employees' performance in the public sector. Similar findings have been reported in other studies too (Wallace, Edward, Arnorld, \& Frazier, 2009).

The five factor model captures the employee performance along with five aspects of a job which are essential part of overall performance. Each factor will covers each particular dimension of employee's performance so that it encompasses the totality of performance. The job factor assess how well an employee does things specifically related to one's job description while career includes the level of necessary skills to progress. Innovator factor cptures the creativity and innovation in one's job and team will cover the working with coworkers and team members. The organization factor measures the extra efforts of employees going above the call in one's duty. Therefore, the role based model is more for the assessment of employeess performance since it takes full context of employee performance. This multidimensional performance model is highly appropriate as claimed by (Welbourne, Johnson, \& Erez, 1998).

However, the present study found the task and contextual performance model of Motowidlo \& Van Scotter, (1994) was also usable for assessing the employee performance in the pubic sector. the fitting of the model adequstely $\left(\chi^{2}=678.9, d f\right.$. $=243, \mathrm{p}<.05$, GFI $=.49$, CFI $=.42, \mathrm{NNFI}=.44, \mathrm{RMSEA}=.33$ ) hints that this model is also valid 
though it is compartaively less valid when compared with role based model of performance. The interesting point to be noted is the fact that the contextual performance dimension does not adequately covers the performance. This is evendent with the fact that items of contextual performance did not loaded with contextual performance. Anyway, the inclusions of dimesions of contexual performance will increase the validity of the model for which a further stduy is recommended. 


\section{References}

Adelle, B. J., \& Boris, K. (2014). Star performers: task and contetual performance are important but are they enoguh? Asia Pacific Journal of Human Resource, 52(1), 110-127.

Befort, N., \& Hattrup, k. (2003). Valuing task and contextual performance: experiences, job roles and ratings of the importance of job behavior. Applied H.R.M. Research, 8(8), 17-32.

Bennett, W., Lance, C. E., \& Wochr, D. J. (2014). Performance measurement: current perspective and future challenges . NY: Psychological Press .

Borman, W. C., \& Motowidlo, S. J. (1993). Expanding the criterion domain to include elements of contextual performance. In $\mathrm{N}$. Schmitt, \& W. C. Borman, Personnel Selection in Organizations (pp. 71-98). San Francisco: Jossey-Bass.

Byrne, B. M. (2010). Structural Equation Modeling (2 ed.). New York: Taylor and Francis.

Campbell, J. P. (1990). Modeling the performance prediction problem in industrial and organizational psychology. In M. D. Dunnetee, \& L. M. Hough, Handbook of industrial and organizational psychology (pp. 687-732). Palo Alto:CA: Consulting Psychologists Press.

Campbell, P. J., Gasser, M. B., \& Oswold, F. L. (1996). The substantive nature of job performance variability. Individual Differences and Behavior in Organizations, 258-299.

Chen, G., \& Klimoski, R. J. (2003). The impact of expectation on newcomer performance in teams as moderated by work 
characteristics, soical exchange and empowerment. Academy of Management Journal, 46(5), 591-607.

Conway, J. M. (1996). Distinguishing contextual performance from task performance for managerial job. Journal of Applied Psychology, 84, 139-162.

Griffin, M. A., Neal, A., \& Parker, S. K. (2007). A new model of work role performance: positive behavior in uncetain and independent context. Academy of Management Journal, 50(2), 327-347.

Harris, K. J., Wheeler, A. R., \& Kacmar, K. M. (2009). LeaderMemeber exchange and emplowerment: Direct and interactive effects on job satisfaction, turnover intentions, and performance. The Leadership Quarterly, 20, 371-382.

Kappagoda, S., Othman, P., Fithri, H. Z., \& Alwis, G. D. (2014). Psychological capital and job performance:the meadiating role of work attitudes. Journal of Human Resource and Sustainability Studies, June.

Katz, D., \& Kahn, R. L. (1978). The soical psychology of organizations (2 ed.). New York: Wiley.

Lee, Y. D., Lian, J. W., \& Chen, C. Y. (1999). A study on the mesuarement of productivity for white cholor employees : A case of electronic industry in Thaivan. Chinese Militory Academy Journal, 14, 345-361.

Luo, Z.-X., Shi, K., Li, W.-D., \& Miao, D.-M. (2008). Construct of Job Performance: evidence from Chinese military soldiers. Asian Journal of Social Psychology(11), 222-231. 
Motowidlo, S. J., \& Schmit, M. J. (1999). Performance assessment in unque jobs. In D. R. Ilegen, \& E. D. Pulakos, The changing nature of performance (pp. 56-86). San Francisco: JosseyBass.

Motowidlo, S. J., \& Van Scotter, J. R. (1994). Evidence that Task Performance Should be Distinguished from Contextual Performance. Journal of Applied Psychology, 79(4), 475-480.

Murphy, P. R., \& Jackson, S. E. (1999). Managing work role performance: challenges for $21 \mathrm{st}$ century organization and employees. In D. R. Ilgen, \& E. D. Pulakos, The Changing Nature of Work Performance (pp. 325-365). San Francisco: Jossey-Bass.

O'Regan, N., Sims, M., \& Ghobadian, A. (2005). High performance: ownership and decision making in SMEs. Management Decisions, 43(3), 382-396.

Organ, D. W. (1997). Organizational citizenship behaviour: It's construct clean-up time. Human Performance, 10(2), 85-97.

Podsdakoff, P. M., MacKenzie, S. B., Paine, J. B., \& Bachrach, D. G. (2000). Organizational citizenship behavior: critical review of the theoretical and empirical litarature and suggesstions for future research. Journal of Management, 26, 513-563.

Randall, L. M., Cropanzano, R., Borman , A. C., \& Birjulin, A. (1999). Organizational politcis and organizational support as predictor of work attitudes, job performance and OCB. Journal of Organizational Behavior, 20(2), 159-174.

Rotundo, M., \& Sackett, P. R. (2002). The relative importance of the task, citizenship and counterproductive performance to global 
rating of job performance:a policy-capturing approach. Journal of Applied Psychology, 87(1), 66.

Shaw, J. D., Delery, E. J., \& Abdulla, H. M. (2003). Organizational commitment and performance among guest workers and citizens of an Arab Country. Journal of Business Research, 56, 1021-1030.

Vigoda-Gadot, E. (2007). Leadership Style, Organizational Politics and Employees' performance. Personal Review, 36(5), 661683.

Wallace, J. C., Edward, B. D., Arnorld, T., \& Frazier, L. M. (2009). Work stress, role-based performance and the moderating influence of organizational support. Journal of Applied Psychology, 94(1), 254-262.

Welbourne, T. M., Johnson, D. E., \& Erez, A. (1998). The role-based performance scale: validity analysis of a theory-based measure. Academy of Management Journal, 41(5), 540-555. 